Eastern Illinois University

The Keep

Faculty Research \& Creative Activity

Biological Sciences

January 2000

\title{
Raccoons as potential vectors of radionuclide contamination to human food chains from a nuclear industrial site
}

\author{
Karen F. Gaines \\ Eastern Illinois University, kfgaines@eiu.edu \\ Christine G. Lord \\ Rutgers University \\ C. Shane Boring \\ Rutgers University \\ I. Lehr Brisbin Jr. \\ Savannah River Ecology Laboratory \\ Michael Gochfeld \\ Rutgers University \\ See next page for additional authors
}

Follow this and additional works at: http://thekeep.eiu.edu/bio_fac

Part of the Biology Commons

\section{Recommended Citation}

Gaines, Karen F.; Lord, Christine G.; Boring, C. Shane; Brisbin, I. Lehr Jr.; Gochfeld, Michael; and Burger, Joanna, "Raccoons as potential vectors of radionuclide contamination to human food chains from a nuclear industrial site" (2000). Faculty Research \& Creative Activity. 59.

http://thekeep.eiu.edu/bio_fac/59

This Article is brought to you for free and open access by the Biological Sciences at The Keep. It has been accepted for inclusion in Faculty Research \& Creative Activity by an authorized administrator of The Keep. For more information, please contact tabruns@eiu.edu. 
Authors

Karen F. Gaines, Christine G. Lord, C. Shane Boring, I. Lehr Brisbin Jr., Michael Gochfeld, and Joanna Burger 


\section{allen press}

Raccoons as Potential Vectors of Radionuclide Contamination to Human Food Chains from a Nuclear Industrial Site

Author(s): Karen F. Gaines, Christine G. Lord, C. Shane Boring, I. Lehr Brisbin, Jr., Michael

Gochfeld, Joanna Burger

Source: The Journal of Wildlife Management, Vol. 64, No. 1 (Jan., 2000), pp. 199-208

Published by: Allen Press

Stable URL: http://www.jstor.org/stable/3802991

Accessed: 07/12/2010 14:25

Your use of the JSTOR archive indicates your acceptance of JSTOR's Terms and Conditions of Use, available at http://www.jstor.org/page/info/about/policies/terms.jsp. JSTOR's Terms and Conditions of Use provides, in part, that unless you have obtained prior permission, you may not download an entire issue of a journal or multiple copies of articles, and you may use content in the JSTOR archive only for your personal, non-commercial use.

Please contact the publisher regarding any further use of this work. Publisher contact information may be obtained at http://www.jstor.org/action/showPublisher?publisherCode=acg.

Each copy of any part of a JSTOR transmission must contain the same copyright notice that appears on the screen or printed page of such transmission.

JSTOR is a not-for-profit service that helps scholars, researchers, and students discover, use, and build upon a wide range of content in a trusted digital archive. We use information technology and tools to increase productivity and facilitate new forms of scholarship. For more information about JSTOR, please contact support@jstor.org. 


\title{
RACCOONS AS POTENTIAL VECTORS OF RADIONUCLIDE CONTAMINATION TO HUMAN FOOD CHAINS FROM A NUCLEAR INDUSTRIAL SITE
}

KAREN F. GAINES,' Savannah River Ecology Laboratory, P.O. Drawer E, Aiken SC 29802, USA

CHRISTINE G. LORD, Nelson Biological Laboratories and Environmental and Occupational Health Sciences Institute, Rutgers

University, Piscataway, NJ 08855, USA

C. SHANE BORING, Nelson Biological Laboratories and Environmental and Occupational Health Sciences Institute, Rutgers University, Piscataway, NJ 08855, USA and Savannah River Ecology Laboratory, P.O. Drawer E, Aiken SC 29802, USA

I. LEHR BRISBIN, JR., Savannah River Ecology Laboratory, P.O. Drawer E, Aiken SC 29802, USA

MICHAEL GOCHFELD, Environmental and Occupational Health Sciences Institute, Rutgers University, Piscataway, NJ 08855 , USA

JOANNA BURGER, Nelson Biological Laboratories and Environmental and Occupational Health Sciences Institute, Rutgers University, Piscataway, NJ 08855, USA

\begin{abstract}
Although the raccoon (Procyon lotor) is commonly harvested and consumed throughout the southeastern United States, little is known regarding the fate and effects of environmental pollutants to this species, and the potential for it to act as a contaminant vector to humans or other predators. Muscle and liver tissues were collected from 76 raccoons from locations on and near the Department of Energy's Savannah River Site (SRS) in South Carolina and analyzed for radiocesium $\left({ }^{137} \mathrm{Cs}\right)$. Raccoons were trapped from areas near a former reactor cooling reservoir known to be contaminated from former nuclear production activities, a stream drainage system also known to have received ${ }^{137} \mathrm{Cs}$ contamination from low level releases, and 4 on-site reference areas that have been unimpacted by nuclear production activities. Raccoons from 3 hunting areas $3-15 \mathrm{~km}$ of SRS were used as off-site reference samples. ${ }^{137} \mathrm{Cs}$ levels differed between the 3 treatment groups (contaminated, on-site reference, off-site reference) for both muscle and liver tissues. Muscle and liver samples from raccoons from on-site reference areas were higher in ${ }^{137} \mathrm{Cs}$ than those from off-site reference animals. ${ }^{137} \mathrm{Cs}$ in raccoon tissues from contaminated habitats exceeded levels in the pooled reference animals. The 2 contaminated areas differed in ${ }^{137} \mathrm{Cs}$ tissue levels. Only 1 of 20 raccoons from contaminated sites on the SRS exceeded the European Economic Community (EEC) limit for ${ }^{137} \mathrm{Cs}$ in edible muscle tissue of $0.6 \mathrm{~Bq}{ }^{137} \mathrm{Cs} / \mathrm{g}$ freshweight edible muscle. Further, none of the raccoons from the on-site reference areas exceeded EEC limits for muscle. It is unlikely that the hunting public faces any significant risk from exposure to raccoons from the SRS. Although some raccoons might stray off the SRS which is closed to public access, most of the heavily contaminated areas are not adjacent to the edges of the site, decreasing the potential for off-site movement of contaminated animals.
\end{abstract}

JOURNAL OF WILDLIFE MANAGEMENT 64(1):199-208

Key words: contaminant transport, Procyon lotor, radiocesium, raccoon, risk assessment, Savannah River Site, South Carolina.

Understanding the fate and effects of environmental pollutants is an important concern, particularly when wildlife may act as vectors of contamination to the food chain of humans or other predators. The raccoon has seldom been considered in this regard, although it is commonly harvested and consumed throughout the southeastern United States (South Carolina Department of Natural Resources 1996a,b). Several characteristics of raccoons make them potential agents of contaminant movement and dispersal including: (1) a broadly omnivorous diet which includes components of both terres-

\footnotetext{
${ }^{1}$ E-mail: gaines@srel.edu
}

trial and aquatic food chains (Lotze and Anderson 1979, Khan et al. 1995); (2) their ability and proclivity to travel extended distances (Glueck et al. 1988, Walker and Sunquist 1997, Gehrt and Fritzell 1998); and (3) a propensity to utilize human-altered habitats in combination with an ability to move freely in and out of toxic waste sites (Hoffmann and Gottschang 1977, Clark et al. 1989, Khan et al. 1995).

Numerous studies of the chemical cycling and kinetics of ${ }^{137} \mathrm{Cs}$ have provided insight into its environmental behavior and potential biological uptake by game species (Brisbin 1991, Colwell et al. 1996, Peters and Brisbin 1996). Radiocesium has a moderately long physical halflife (30.2 yr) and thus can persist for prolonged 
periods in contaminated habitats. However, the biological half-life of ${ }^{137} \mathrm{Cs}$ for many species can be considerably shorter. We found no studies concerning the biological half-life of ${ }^{137} \mathrm{Cs}$ in raccoons. It has been documented that the biological half-life in the gray fox (Urocyon cinereoargenteus) is around 30 days, which compares closely with that of the pig, both of which are omnivorous species like the raccoon (Jenkins et al. 1969). Further, it has been shown that species having similar ${ }^{137} \mathrm{Cs}$ biological half-lives could have different ${ }^{137} \mathrm{Cs}$ ecological half-lives depending on characteristics of the contaminated habitats (Brisbin 1991). Since ${ }^{137} \mathrm{Cs}$ accumulates in edible muscle tissue (Narayanyan and Eapen 1971, Brisbin and Smith 1975, Potter et al. 1989), it can enter the human food chain when hunters near such sites consume contaminated meat.

Many radionuclide studies have focused on highly mobile avian species because they can rapidly transport accumulated radionuclides over long distances to the hunting public. Studying the potential for game mammals to accumulate ${ }^{137} \mathrm{Cs}$ and serve as a direct vector to the hunting public is warranted because of limited home ranges (e.g., vs. migratory game birds) and long-term exposure. To explore this, we examined ${ }^{137} \mathrm{Cs}$ levels in muscle and liver tissues of raccoons inhabiting areas within and surrounding the SRS, a former nuclear production and research facility in South Carolina. We chose raccoons because of their potential to serve as an indicator species for monitoring contaminant uptake and transport. Additionally, life history of raccoons and other furbearers have been studied on the SRS since 1954, 2 years after closure of the site to public access (Kinard 1964, Wood and Odum 1964, Jenkins et al. 1969). Raccoons are commonly hunted in the vicinity of the SRS (Cothran et al. 1991) and may either be consumed by hunters or given away or sold to the local public (South Carolina Department of Natural Resources 1996a)

The first objective of this study was to compare the levels of ${ }^{137} \mathrm{Cs}$ in the liver and muscle of raccoons living in (1) sites known to be contaminated by ${ }^{137} \mathrm{Cs}$ on the SRS, (2) SRS sites that had no history of ${ }^{137} \mathrm{Cs}$ contamination from nuclear activities, and (3) habitats outside of the SRS boundaries. The second objective was to compare ${ }^{137} \mathrm{Cs}$ levels in raccoons residing in different habitats on the SRS, to include a contaminated reactor cooling reservoir and a contami-

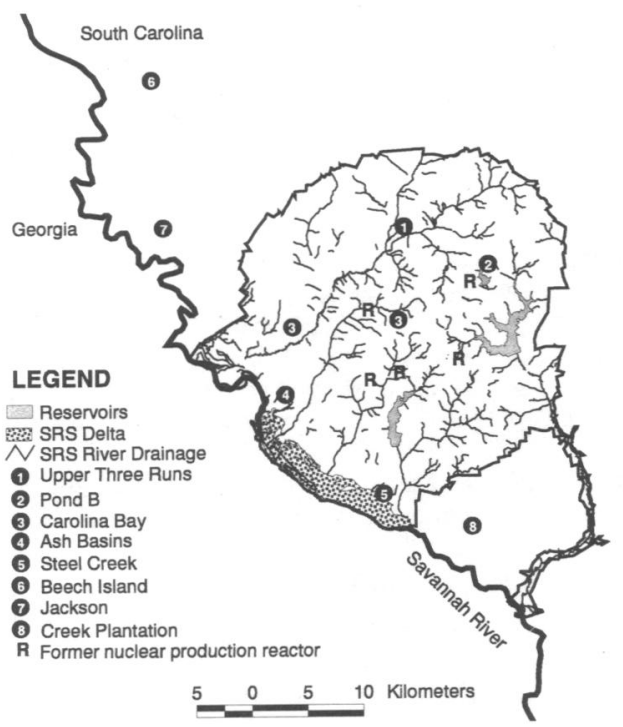

Fig. 1. Map of the U.S. Department of Energy's Savannah River Site showing wetlands and river drainage systems. Capital letters ("R") indicate the locations of former nuclear production reactors, some of which are known to have served as past sources of radiocesium releases (see text).

nated stream floodplain. Our final objective was to estimate the relative health risks to humans from consumption of raccoons at observed ${ }^{137} \mathrm{Cs}$ levels in edible muscle tissue. This work was part of a larger study on the part of the Consortium for Risk Evaluation with Stakeholder Participation (CRESP) and the Savannah River Ecology Laboratory to develop bioindicators of both human and ecological health.

\section{STUDY AREA}

The SRS is a $778 \mathrm{~km}^{2}$ former nuclear production and current research facility located in west-central South Carolina $\left(33.1^{\circ} \mathrm{N}, 81.3^{\circ} \mathrm{W}\right.$; Fig. 1) that was closed to public access in 1952. In 1972, the entire SRS was designated as the nation's first National Environmental Research Park to provide tracts of land where the effects of human impacts upon the environment could be studied (Davis and Janacek 1997). Workman and McLeod (1990) provide a detailed description of the terrestrial and aquatic habitats of the SRS. Raccoons were collected from 6 locations on the SRS, 4 of which have not been directly impacted by ${ }^{137}$ Cs-contamination from the SRS (Fig. 1). Raccoons from SRS areas known to have been directly contaminated by ${ }^{137} \mathrm{Cs}$ releases were collected from an 87-ha former reactor cooling reservoir (Pond B) and a disturbed stream flood plain (Steel Creek). Both of these 
systems have been intensely studied with regard to the bioaccumulation of ${ }^{137} \mathrm{Cs}$ in resident flora and fauna (Brisbin et al. 1974a,b; Evans et al. 1983; Gladden et al. 1985; Brisbin et al. 1989; Whicker et al. 1990; Kennamer et al. 1993, 1998). Pond B received cooling water discharges from the SRS R-Reactor (shut down in 1964) that were contaminated with ${ }^{137} \mathrm{Cs}$ from leaking reactor fuel elements. Peak introductions of ${ }^{137} \mathrm{Cs}$ occurred during 1963 and 1964 and amounted to $5.7 \times 10^{12}$ becquerels $(\mathrm{Bq})$ of ${ }^{137}$ Cs (Ashley and Zeigler 1980). The Steel Creek watershed drains into an inundated riverine swamp delta that is contiguous to the Savannah River. Two production reactors discharged effluents into Steel Creek containing cooling water mixed with purge water from basins used to store irradiated reactor fuel and target assemblies. From 1954 through 1978, approximately $1.06 \times 10^{13} \mathrm{~Bq}{ }^{137} \mathrm{Cs}$ that leaked from defective experimental fuel assemblies were discharged into Steel Creek via this purge water (Ashley and Zeigler 1980).

Two of the 4 sites on the SRS that were not directly contaminated by plant operations (hereafter "reference") were Carolina bays (Dry Bay and Rainbow Bay; Fig. 1), which are natural elliptical depressions that vary in size and in the degree to which they retain water (Sharitz and Gibbons 1982, Ross 1987). The third reference site on the SRS was an undisturbed natural stream flood plain system (Upper Three Runs-Tinker Creek area). Upper Three Runs Creek (UTR) has been used previously as a standard reference for comparing other upper coastal plain stream areas of the southeastern United States. The fourth reference site on the SRS was a coal-fired power plant (D-Area basins), which discharges sluiced fly and bottom ash into a series of open settling basins. Past investigations of the D-Area basins, and nearby Beaver Dam Creek, have found enrichment of water, sediments, and biota with $\mathrm{Al}, \mathrm{As}, \mathrm{Cd}, \mathrm{Cr}$, $\mathrm{Cu}, \mathrm{Fe}, \mathrm{Hg}, \mathrm{Mn}, \mathrm{Ni}, \mathrm{Se}$, and $\mathrm{Zn}$ (Cherry and Gutherie 1977, Evans and Giesy 1978, Alberts et al. 1985, Sandhu et al. 1993, McCloskey and Newman 1995, Rowe et al. 1996). However, no direct ${ }^{137} \mathrm{Cs}$ contamination from SRS activities has occurred at this location.

Raccoons were also collected from nearby public hunting grounds to serve as an off-site reference group (Fig. 1). These sites included an area located approximately $8 \mathrm{~km}$ west-northwest of SRS (Jackson), an area located approx- imately $15 \mathrm{~km}$ northwest of SRS (Beech Island), and an area approximately $3 \mathrm{~km}$ from the southern SRS boundary (Creek Plantation). All 3 hunting areas are part of the bottomland hardwood floodplain ecosystem of the Savannah River, which extends into the SRS along the site's southwestern border.

\section{METHODS}

\section{Raccoon Trapping and Sampling}

Raccoons $(n=52)$ were collected on SRS between December 1996 and June 1997 from $2{ }^{137}$ Cs-contaminated sites $(n=21)$ and 3 reference sites $(n=31)$. Raccoons were collected using baited traps (T. Fox, manufacturer, Batesburg South Carolina, USA) set in the afternoon and checked the following morning. Raccoons were transported to the laboratory, euthanized, and dissected immediately. On the SRS we only used male raccoons for this study to control for possible variation due to sex and to prevent removing pregnant females or females with young from the population. Off-site reference raccoons $(n=24)$ were collected during the statewide hunting season between January and February 1997 and frozen individually in labeled plastic bags until dissection. Since it was not possible to determine the sex of the raccoon while hunting, females were included $(n=9)$. These females were used within our analyses because ${ }^{137} \mathrm{Cs}$ levels in tissues from these raccoons were not different from the males collected from the same sites (Wilcoxon 2-sample test: $Z=-1.68, P=0.09$ ). We removed livers $(10-20 \mathrm{~g})$ and gastrocnemius muscles $(10-20 \mathrm{~g})$ and froze tissues in scintillation vials for later ${ }^{137}$ Cs analyses. We followed an animal welfare protocol approved by the University of Georgia Institutional Animal Care and Use Committee (A960205) and Rutgers University (97-017).

\section{${ }^{137} \mathrm{Cs}$ Determinations}

We determined ${ }^{137} \mathrm{Cs}$ count rates of wet muscle and liver tissues using a Packard Auto-Gamma A5530 counting system (Packard Instrument, Meriden, Connecticut, USA) with a 7.62$\mathrm{cm}$ thallium-activated NaI crystal of throughhole design with a counting window of 550-760 $\mathrm{keV}$. Accuracy of the instrument was assessed by calibrating it prior to every counting sequence using a certified calibration standard. Counting time per sample was 60 min for samples from contaminated areas and $500 \mathrm{~min}$ for samples from reference areas. Counting times 
for each group were based upon preliminary analyses of the sample count rate for all on-site reference samples and sample masses, relative to resultant minimal detectable concentrations (MDC). To estimate tissue wet mass ${ }^{137} \mathrm{Cs}$ concentrations $(\mathrm{Bq} / \mathrm{g})$, we first adjusted sample gross count rates for background count rates. We then compared the adjusted count rates of samples to similarly adjusted count rates of aqueous standards approximating the sample geometry and containing known quantities of ${ }^{137} \mathrm{Cs}$. Background count rates were recorded following every third sample. This also provided a measure to assure the precision of the instrument over the analysis period. Count rates of standards were determined daily for samples counted for $60 \mathrm{~min}$ and twice a week for samples run for $500 \mathrm{~min}$. Standard count times corresponded to count times of samples to which they would be compared. The MDC's were calculated following procedures described by Currie (1968).

\section{Statistical Analyses}

We first examined ${ }^{137} \mathrm{Cs}$ distributions using Kolomogorov-D statistics (PROC UNIVARIATE, v.6.12; SAS Institute 1988). Tests of hypotheses that these data were random samples from normal distributions and tests of homogeneity of variances were all rejected $(P<0.05)$ even after efforts to transform the data failed. Therefore, we used Kruskal-Wallis tests (chisquare approximation; PROC NPARIWAY, v.6.12; SAS Institute 1988) to test for overall differences among the 3 test groups (on-site contaminated, on-site reference, and off-site reference). Wilcoxon 2-Sample tests ( $Z$ approximation; PROC NPARIWAY, v.6.12; SAS Institute 1988) were used to determine significant differences between on-site and off-site reference groups and for differences between areas affected by plant operations vs. all other areas. This test was also used to determine differences between habitats for the 2 on-site contaminated areas (Steel Creek vs. Pond B). Negative values for ${ }^{137} \mathrm{Cs}$ concentrations occasionally resulted from sample count rates that were below background. These negative and positive values which fell below their respective MDC's were not censored from the data analysis since to do so would bias the overall variance and could bias the analysis (Gilbert and Kinnison 1981, Newman et al. 1989). All statistical tests were considered significant at $P \leq 0.05$ and Bonfer-

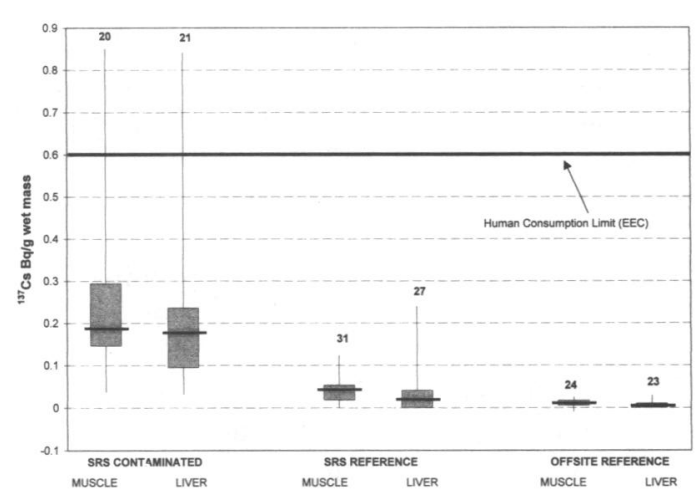

Fig. 2. Concentrations of radiocesium in raccoon tissues collected between December 1996 and June 1997 from the U.S. Department of Energy's Savannah River Site and offsite public hunting areas. Vertical lines represent ranges, boxes represent $25 \%-75 \%$ quartile limits, and horizontal lines indicate medians. For both muscle and liver, the SRS reference tissues were significantly higher than the off-site tissues $(P<0.05)$. Tissues from the contaminated site were significantly different from the pooled (SRS and offsite) reference sites $(P<0.05)$. The bold horizontal line represents the limit for radiocesium contamination of meat for human consumption (European Economic Community 1986), and numbers indicate sample sizes.

roni corrections were performed when appropriate.

\section{RESULTS}

Those samples below their individual MDC ranged from $0.01-0.10 \mathrm{~Bq} / \mathrm{g}$ wet tissue mass for this study. Radiocesium concentrations of all off-site raccoon liver tissues and $96 \%$ of off-site muscle tissues were below their respective MDC's. However, $58 \%$ of liver and $72 \%$ of muscle tissues from on-site reference areas contained ${ }^{137}$ Cs levels above their MDC's. All liver and muscle tissues from on-site contaminated areas contained ${ }^{137}$ Cs levels above their MDC's. Radiocesium levels differed among the 3 test groups (contaminated, on-site reference, offsite reference) for both muscle (Kruskal-Wallis ANOVA: $\left.\chi^{2}{ }_{2}=43.90, P=0.0001\right)$ and liver (Kruskal-Wallis ANOVA: $\chi^{2}{ }_{2}=44.81, P=$ 0.0001; Fig. 2). Radiocesium levels differed between on-site and off-site reference groups for both muscle (Wilcoxon 2-sample test: $Z=$ -4.23, $P=0.0001$ ) and liver (Wilcoxon 2-sample test, $Z=-2.69, P=0.0071$; Fig. 2), with on-site reference areas showing higher levels of contamination in both tissues. Radiocesium levels were significantly higher in raccoons collected from contaminated areas than those collected from pooled reference areas (on-site and off-site) for both muscle (Wilcoxon 2-sample test: $Z=6.36, P=0.0001$ ) and liver (Wilcoxon 
Table 1. Concentrations of radiocesium (Bq/g wet mass) in raccoon tissues collected between December 1996 and June 1997 from 2 contaminated areas on the U.S. Department of Energy's Savannah River Site. Both muscle and liver differed $(P<0.05)$ between the 2 contaminated areas.

\begin{tabular}{|c|c|c|c|c|c|c|c|c|}
\hline \multirow[b]{2}{*}{ Tissue } & \multicolumn{4}{|c|}{ Pond B } & \multicolumn{4}{|c|}{ Steel Creek } \\
\hline & $n$ & $\overline{\bar{x}}$ & Median & Range & $n$ & $\overline{\bar{x}}$ & Median & Range \\
\hline Muscle & 9 & 0.367 & 0.314 & $0.171-0.851$ & 11 & 0.144 & 0.146 & $0.040-0.272$ \\
\hline Liver & 10 & 0.301 & 0.233 & $0.066-0.841$ & 11 & 0.117 & 0.105 & $0.032-0.279$ \\
\hline
\end{tabular}

2-sample test, $Z=6.35, P=0.0001$; Fig. 2). Finally, raccoons from the 2 contaminated areas (Steel Creek and Pond B) differed in ${ }^{137} \mathrm{Cs}$ levels for both muscle (Wilcoxon 2-sample test, $Z$ $=3.34, P=0.0008$ ) and liver (Wilcoxon 2-sample test, $Z=2.71, P=0.0067$; Table 1 ), with Pond $\mathrm{B}$ being the highest in both cases.

\section{DISCUSSION}

Animals inhabiting on-site areas that received direct contamination from SRS activities were an order of magnitude higher and showed higher levels of variance in ${ }^{137} \mathrm{Cs}$ than those from the combined reference groups. Thus, raccoon foraging habits and resource utilization may be sufficiently limited to allow them to reflect differences in habitat contamination patterns at these spatial scales. However, ${ }^{137} \mathrm{Cs}$ levels in the on-site reference group were also significantly higher than raccoons from the off-site reference group. This suggests that even in areas that have not been directly subjected to ${ }^{137} \mathrm{Cs}$ releases, some SRS raccoons are still being exposed and accumulate more ${ }^{137} \mathrm{Cs}$ than off-site populations. Seasonal differences in raccoon diets and-or overall fallout levels of ${ }^{137} \mathrm{Cs}$ over time might have contributed to differences in ${ }^{137} \mathrm{Cs}$ levels between the 2 reference groups. Studies on the SRS have shown seasonal differences based on these factors (fall-winter vs. springsummer) in white-tailed deer (Odocoileus virginianus; Rabon 1968) and in feral hogs (Sus Scrofa; Stribling et al. 1986). Differences may also occurred because off-site raccoons were collected in late winter while on-site reference raccoons were collected late winter to early spring.

Differences in ${ }^{137} \mathrm{Cs}$ between the 2 reference groups may also be due, at least in part, to the nature of the geology and associated soil types between on-site and off-site foraging areas (Table 2). Soils with higher clay content may tend to bind available ${ }^{137} \mathrm{Cs}$, depending on mineralogy, thus making it less bioavailable. Such clays with a high affinity for poorly hydrated cations such as ${ }^{137} \mathrm{Cs}$ are prevalent in the soils and subsurface sediments on and around SRS (Strom and Kaback 1992, Seaman et al. 1996). Further, there is an inverse relationship between concentration of available potassium in soil and uptake of ${ }^{137} \mathrm{Cs}$ (Nishita et al. 1960) since plants growing in potassium-deficient soils take up the available ${ }^{137} \mathrm{Cs}$ as a potassium substitute (Haselow et al. 1989, Looney et al. 1990, Haselow 1990). Soils from the on-site reference areas where raccoons showed higher tissue ${ }^{137} \mathrm{Cs}$ concentrations (e.g. UTR) were predominantly sandy and would tend to leach potassium and be less likely to bind ${ }^{137} \mathrm{Cs}$ cations. Conversely, areas with soils of higher organic matter and high clay content (e.g., off-site areas such as Jackson) may tend to bind cations such as ${ }^{137} \mathrm{Cs}$ especially if the clays are illitic in nature (Comans and Hockley 1991). This in turn would make ${ }^{137} \mathrm{Cs}$ less bioavailable.

Radiocesium differences in these reference raccoon populations may also be explained by home range size, with on-site raccoons possibly feeding on some occasions in contaminated areas. Trap-recapture studies in the early 1960's on the SRS indicated that male raccoons traveled $1.4 \mathrm{~km}$ between trap sites (Cunningham 1962), which would make it possible for SRS raccoons to reside within uncontaminated reference areas and yet still forage in some contaminated areas.

Because raccoons may move long distances (up to $4.3 \mathrm{~km}$; Walker and Sunquist 1997), it is possible for raccoons to leave contaminated areas and move to off-site areas using the floodplain corridor. Raccoon tissues obtained from off-site locations were very low in ${ }^{137} \mathrm{Cs}$, suggesting that sampled individuals from these populations were not residing in ${ }^{137} \mathrm{Cs}$-contaminated areas on the SRS. The risk of transport of ${ }^{137} \mathrm{Cs}$ from the SRS to off-site locations by raccoons would probably be higher for raccoons inhabiting the Savannah River floodplain system than for those associated with the contaminated reservoirs, since the former represent large con- 


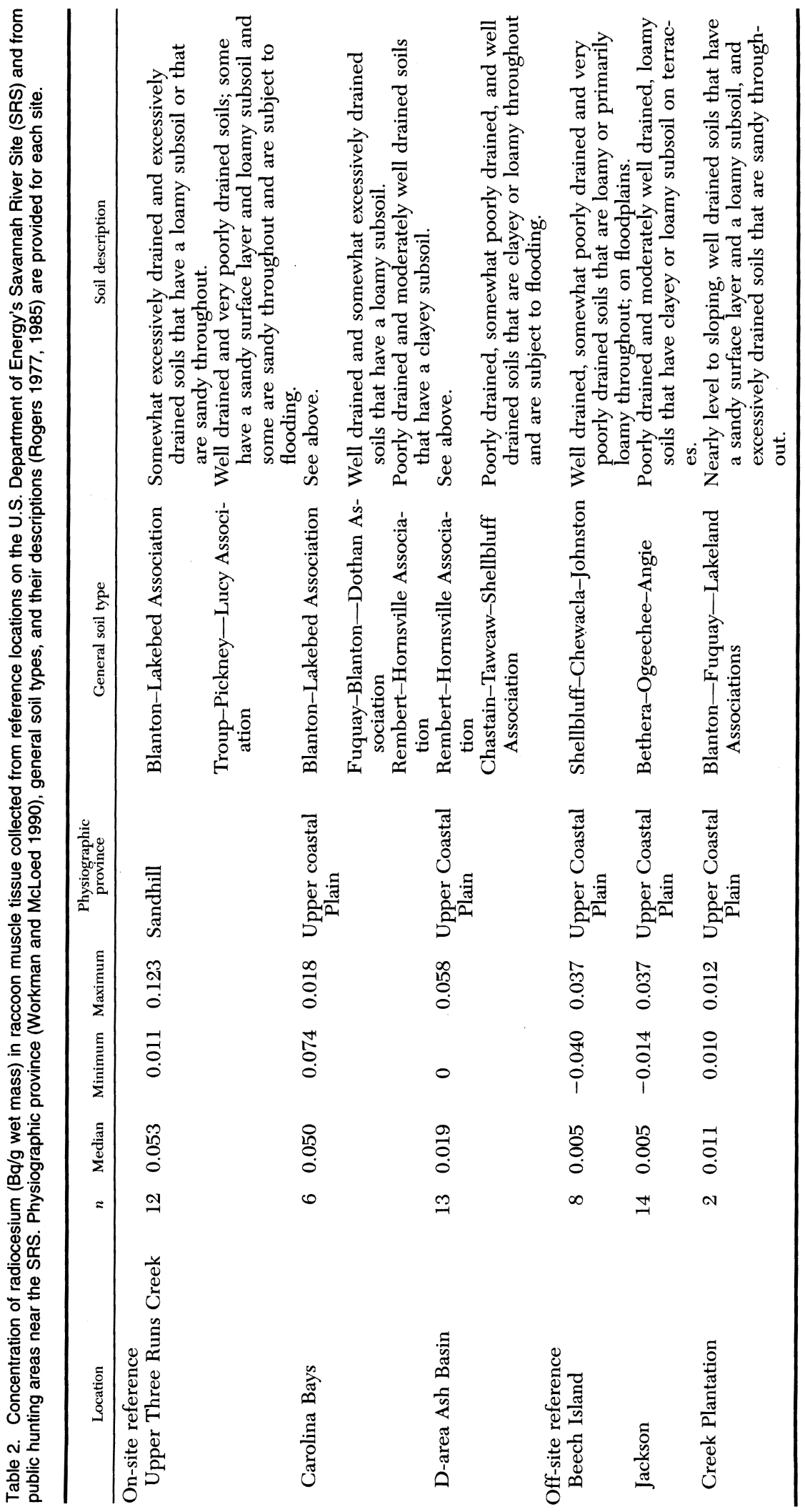


tiguous areas of suitable habitat that lead offsite.

Raccoon tissues from the Pond B reservoir area contained significantly higher ${ }^{137} \mathrm{Cs}$ concentrations than those from the Steel Creek Delta-Savannah River floodplain area. Our data suggest that ${ }^{137} \mathrm{Cs}$ may be more bioavailable to raccoons in the Pond $B$ reservoir system than the Steel Creek floodplain of SRS, even though the latter originally received larger inputs of this contaminant (Ashley and Zeigler 1980). This finding is consistent with previous studies examining ${ }^{137} \mathrm{Cs}$ in wood duck (Aix sponsa) eggs from the same 2 areas (Kennamer et al. 1993, 1995). The longer retention of the original ${ }^{137} \mathrm{Cs}$ released to Pond B vs. that to Steel Creek (Brisbin 1991), together with the seasonal remobilization of ${ }^{137} \mathrm{Cs}$ from sediments to the water column in the hypolimnion in Pond B (Alberts et al. 1979, 1987; Whicker et al. 1990), could account for its longer persistence in the biota of the Pond B area.

\section{MANAGEMENT IMPLICATIONS}

Raccoons are trapped for their fur and hunted for both sport and food in South Carolina. Raccoons accounted for $20 \%$ of the state's total 1995-96 commercial fur harvest (South Carolina Department of Natural Resources 1996a). Raccoon hunting is a growing sport, among both young and experienced hunters, with participation in raccoon field trials nearly doubling in the last 10 years (South Carolina Department of Natural Resources 1996b). Despite the increase in sport hunting for raccoons, there are few data on the consumption of this species by the public. In South Carolina, the raccoon hunting season is usually from mid-September to mid-March, with no bag or possession limit. Thus, a diligent hunter who enjoyed the sport of raccoon hunting and ate the meat could legally consume as much raccoon meat as desired. A survey of attendees at a sportsmen's exposition in Columbia, South Carolina in 1998 revealed that nearly $10 \%$ of those interviewed said they ate raccoon, with an average serving size equivalent to $350 \mathrm{~g}$ (J. Burger, unpublished data). Those who ate raccoon averaged only 1 meal per year, with a maximum of 12 meals per year. It is likely however that few people in lower economic strata attended this event, and therefore subsistence hunters who might consume raccoons more frequently may have been underrepresented. Based on the above con- sumption pattern and the median ${ }^{137} \mathrm{Cs}$ level in the raccoon muscle $\left(0.182 \mathrm{~Bq}{ }^{137} \mathrm{Cs} / \mathrm{g}\right)$ from contaminated sites, a hunter could consume no more than 18 meals of SRS raccoon meat per year (or $6.43 \mathrm{~kg}$ of meat per year), without exceeding the U.S. Food and Drug Administration's and U.S. Environmental Protection Agency's most conservative action level of a $1 \times 10^{-6}$ excess lifetime cancer risk (Rodricks 1992; see Kennamer et al. 1998 for calculations). Further, muscle of only 1 of 20 raccoons from contaminated sites on the SRS exceeded the EEC limit of $0.60 \mathrm{~Bq}{ }^{137} \mathrm{Cs} / \mathrm{g}$ (EEC 1986) and no muscle samples of raccoons from the reference areas on SRS or off-site exceeded the EEC limit.

Public hunting is allowed on the Crackerneck Wildlife Management Area (WMA) adjacent to the SRS, but access is limited to only 30 days a year, during the daylight hours (Sanchez and Burger 1998). Most hunters use Crackerneck WMA for white-tailed deer, and not raccoons because night hunting is not allowed. Although some raccoons might move off SRS, most of the heavily contaminated areas are not adjacent to the borders of the site or in the Savannah River swamp, with the exception of the Steel Creek delta, thus limiting the potential for off-site movement of contaminated animals. Thus, as long as public access for the hunting of raccoons is restricted from the on-site contaminated areas sampled in this study, it is unlikely that the consumption of ${ }^{137} \mathrm{Cs}$-contaminated meat presents any meaningful health concern for the hunting public in the vicinity of SRS. Further, long-term studies on SRS addressing issues of ecological half-life in several game species have indicated that there have been long-term decreases in ${ }^{137} \mathrm{Cs}$ body burdens as this isotope undergoes physical decay (Brisbin 1991, Brisbin and Kennamer 2000). However, these studies have also shown that disturbances can further remobilize this contaminant, thus increasing its bioavailability and making it difficult to model its effective ecological half-life.

The consumption of contaminated raccoon meat would be only 1 possible route of human exposure. Any comprehensive risk assessment should also include estimates of the risk from other contaminants in all hunted species. Such a comprehensive risk estimate should also estimate external exposure to gamma radiation from contaminated sediments and particulate inhalation while hunting or otherwise residing within contaminated areas (Whicker et al. 
1993). Although the different forms of contaminants may vary by species and between sites, studies as reported here can serve as a model for ways in which data for contaminant burdens can be used to provide general estimates of the health risks that would be associated with the consumption of game by the hunting public.

\section{ACKNOWLEDGMENTS}

We thank W. L. Stephens, Jr. for contributing to the experimental design of this study and for his expertise and contribution in the field. Comments by E. L. Peters, R. A. Kennamer, Buddy Baker, B. D. Goldstein, C. Powers, T. E. Phillippi, J. M. Novak, and 2 anonymous reviewers helped improve the manuscript. We also acknowledge J. M. Novak for his statistical consultation. We thank C. S. Romanek and J. C. Seaman for advice concerning geology and soil geochemistry. This project was funded through Financial Assistance Award DE-FC09-96SR18546 from the U.S. Department of Energy to the University of Georgia Research Foundation and by the Consortium for Risk Evaluation with Stakeholder Participation (funded through the Department of Energy Cooperative Agreement AI\#DE-FC01-95EW55084).

\section{LITERATURE CITED}

Alberts, J. J., L. J. Tilly, and T. J. Vigerstad. 1979. Seasonal cycling of cesium-137 in a reservoir. Science 203:649-651.

- J. W. Bowling, AND K. A. ORLandini. 1987. The effect of seasonal anoxia on the distribution of ${ }^{238} \mathrm{Pu},{ }^{239,240} \mathrm{Pu},{ }^{241} \mathrm{Am},{ }^{244} \mathrm{Cm}$, and ${ }^{137} \mathrm{Cs}$ in pond sediments of the southeastern United States. Pages 371-390 in J. E. Pinder, III., J. J. Alberts, K. W. McLeod, and R. G. Schreckhise, editors. Proceedings of the symposium on environmental research on actinide elements. CONF841142 (DE86008713), National Technical Information Service, Springfield, Virginia, USA.

- - M. C. NEWMan, AND D. W. Evans. 1985. Seasonal variations of trace elements in dissolved and suspended loads for coal ash ponds and pond effluents. Water, Air and Soil Pollution 26:111128.

Ashley, C., AND C. C. ZEIGLER. 1980. Releases of radioactivity at the Savannah River Plant, 1954 through 1978. E.I. Dupont de Nemours and Company Report DPSPU.75-25-1, Aiken, South Carolina, USA.

Brisbin, I. L., JR., 1991. Avian radioecology. Pages 69-140 in D. M. Power, editor. Current ornithology. Volume 8. Plenum Publishing Corporation, New York, New York, USA.

—, R. J. Beyers, R. W. DAPSON, R. A. Geiger, J. B. Gentry, J. W. Gibbons, M. H. SMith, AND
S. K. Woods. 1974a. Patterns of radiocesium in the sediments of a stream channel contaminated by production reactor effluents. Health Physics 27: 19-27.

- D. D. Breshears, K. L. Brown, M. LadD, M. H. Smith, M. W. SMith, AND A. L. Towns. 1989. Relationships between levels of radiocesium in components of terrestrial and aquatic food webs of a contaminated streambed and floodplain community. Journal of Applied Ecology 26:173182.

$\longrightarrow$, AND R. A. Kennamer. 2000. Long-term studies of radionuclide contamination of migratory waterfowl at the Savannah River Site: implications for habitat management and nuclear waste site. Studies in Avian Biology 1999: In

press. centrations in whole-body homogenates and several body compartments of naturally contaminated white-tailed deer. Pages 542-556 in J. B. Gentry and M. H. Smith, editors. Mineral cycling in southeastern ecosystems. National Technical Information Service, Springfield, Virginia, USA.

- , M. A. Staton, J. E. Pinder, III, and R. A. GEIGER. 1974b. Radiocesium concentrations of snakes from contaminated and non-contaminated habitats of the AEC Savannah River Plant. Copeia 1974:501-506.

Cherry, D. S., AND R. K. Gutherie. 1977. Toxic metals in surface waters from coal ash. Water Resources Bulletin 13:1227-1236.

Clark, D. R., JR., P. A. Ogasawara, G. J. SMith, AND H. M. OHLENDORF. 1989. Selenium accumulation by raccoons exposed to irrigation drainwater at Kesterson National Wildlife Refuge, California, 1986. Archives of Environmetal Contamination and Toxicology 18:787-794.

Colwell, S. V., R. A. KENNAMER, AND I. L. Brisbin, JR. 1996. Radiocesium patterns in wood duck eggs and nesting females in a contaminated reservoir. Journal of Wildlife Management 60:186194.

Cothran, E. G., M. H. Smith, J. O. WolfF, and J. B. GENTRY. 1991. Mammals of the Savannah River Site. Publication SRO-NERP-21, Savannah River Ecology Laboratory, Aiken, South Carolina, USA.

Comans, R. J., AND D. E. Hockley. 1991. Kinetics of cesium sorption on illite. Geochimica et Acta 56:1157-1164.

Currie, L. A. 1968. Limits for qualitative detection and quantitative determination. Analytical Chemistry 40:586-593.

Cunningham, E. R. 1962. A study of the eastern raccoon Procyon lotor (L.) on the Atomic Energy Commission Savannah River Plant. Thesis, University of Georgia, Athens, Georgia, USA.

DAvis, C. E., AND L. L. JANECEK. 1997. DOE research set-aside areas of the Savannah River Site. Publication SRO-NERP-25, Savannah River Ecology Laboratory, Aiken, South Carolina, USA.

Evans, D. W., AND J. P. GIESY, JR. 1978. Trace metal concentrations in a stream-swamp system receiving coal ash effluent. Pages 782-790 in M. K. 
Wali, editor. Ecology and coal resources development. Volume 2. Grand Forks, North Dakota, USA.

- J. J. Alberts, and R. A. I. ClakK. 1983. Reversible ion-exchange fixation of cesium-137 leading to mobilization from reservoir sediments. Geochimica et Cosmochimica Acta 47:10411049.

EuRoPEAN ECONOMIC COMMUNITY. 1986. Derived reference levels as a basis for the control of foodstuffs following a nuclear accident: a recommendation from the group of experts set up under Article 31 of the Euratom Treaty. European Economic Community Regulation 170/86, Brussels, Belgium.

Gehrt, S. D., AND E. K. Fritzell. 1998. Resource distribution, female home range dispersion and male spatial interactions: group structure in a solitary carnivore. Animal Behaviour 55:1211-1227.

GILBERT, R. O., AND R. R. KINNISON. 1981. Statistical methods for estimating the mean and variance from radionuclide data sets containing negative, unreported or less-than values. Health Physics 40:377-390.

Gladden, J. B., K. L. Brown, M. H. SMith, ANd A. L. Towns. 1985. Distribution of $\gamma$ exposure rates in a reactor effluent stream flood plain system. Health Physics 48:49-59.

Glueck, T. F., W. R. Clark, and R. D. ANDREWS. 1988. Raccoon movement and habitat use during the fur harvest season. Wildlife Society Bulletin 16:6-11.

Haselow, J. S., V. Price, D. E. Stephenson, H. W. BLEDSOE, AND B. B. LOONEY. 1989. Reactor operation environmental document. Volume 1. WSRC-RP-89-815, Westinghouse Savannah River Company, Aiken, South Carolina, USA.

HASElow, L. A. 1990. The relationship of radiocesium and potassium in the nutritional ecology of white-tailed deer from the Savannah River Site. Thesis, Purdue University, West Lafayette, Indiana, USA.

HofFmanN, C. O., AND J. L. GotTSChang. 1977. Numbers, distribution, and movements of a raccoon population in a suburban residential community. Journal of Mammalogy 58:623-636.

Jenkins, J. H., J. R. Monroe, and F. B. Golley. 1969. Comparison of fallout of ${ }^{137} \mathrm{Cs}$ accumulation and excretion in certain southeastern mammals. Pages 612-622 in D. J. Nelson and F. C. Evans, editors. Radioecology: proceedings of the 2nd national symposium. U.S. Atomic Energy Commission Report Conf-670503.

Kennamer, R. A., C. D. MCCreedy, AND I. L. BrisBIN, JR. 1993. Patterns of radiociesium contamination in eggs of free-ranging wood ducks. Journal of Wildlife Management 57:716-724.

$\longrightarrow$, AND - 1995. Corrigendum. Journal of Wildlife Management 59:209-220.

, I. L. Brisbin, JR., C. D. MCCREedy, AND J. BURGER. 1998. Radiocesium in mourning doves: effects of a contaminated reservoir drawdown and risk to human consumers. Journal of Wildlife Management 62:497-508.

Khan, A. T., S. J. Thompson, AND H. W. Mielke. 1995. Lead and mercury levels in raccoons from
Macon County, Alabama. Bulletin of Environmental Contamination and Toxicology 54:812816.

KINARD, F. W., JR. 1964. Food habits of the eastern raccoon, Procyon lotor (L.) in west-central South Carolina. Thesis, University of Georgia, Athens, Georgia, USA.

Looney, B. B., C. A. Eddy, M. Ramdeen, J. PiCKETT, V. A. Rogers, P. A. Shirley, AND M. T. SCOTT. 1990. Geochemical and physical properties of soils and shallow sediments at the Savannah River Site. Westinghouse Savannah River Company Publication WSRC-RP-90-0464, Aiken, South Carolina, USA.

LotZE, J., AND S. ANDERSON. 1979. Procyon lotor. Mammalian Species 119:1-8.

MCCloskey, J. T., AND M. C. Newman. 1995. Sediment preference in the Asiatic clam (Corbicula fluminea) and viviparid (Campeloma decisum) as a response to low-level metal and metalloid contamination. Archives of Environmental Contamination and Toxicology 28:195-202.

NARAyanyan, N., AND J. EAPEN. 1971. Gross and subcellular distribution of cesium-137 in pigeon (Columba livia) tissues with special reference to muscles. Journal of Radiation Research 12:51-55.

Newman, M. C., P. M. DiXon, B. B. LOONEY, AND J. E. PINDER, III. 1989. Estimating mean and variance for environmental samples with below detection limit observations. Water Resource Bulletin 25:905-916.

Nishita, H., E. M. Romney, G. U. AleXANDER, AND K. H. LARSON. 1960. Influence of $K$ and Cs on release of Cs-137 from three soils. Soil Science 89:167-176.

Peters, E. L., AND I. L. BRISBIN, JR. 1996. Environmental influences on the ${ }^{137} \mathrm{Cs}$ kinetics of the yellow-bellied turtle (Trachemys scripta). Ecological Monographs 66:115-136.

Potter, C. M., I. L. Brisbin, JR., AND S. G. MCDowELL. 1989. Distribution of ${ }^{137} \mathrm{Cs}$ in the American coot (Fulica americana). Journal of Environmental Radioactivity 9:105-115.

RABON, E. W. 1968. Some seasonal and physiological effects on ${ }^{137} \mathrm{Cs}$ and ${ }^{89,90} \mathrm{Sr}$ content of the whitetailed deer, Odocoileus virginianus. Health Physics 15:37-42.

RODRICKS, J. 1992. Calculated Risks. Cambridge University Press, New York, New York, USA.

ROGERS, V. A. 1977. Soil Survey of Barnwell County Area, South Carolina, Eastern Part. U.S. Government Printing Office, Washington, D.C., USA.

1985. Soil Survey of Aiken County Area of South Carolina. U.S. Government Printing Office, Washington, D.C., USA.

Ross, T. E. 1987. A comprehensive bibliography of the Carolina bays literature. Journal of Elisha Mitchell Scientific Society 103:28-42.

Rowe, C. L., O. M. KINNEY, A. P. FIORI, AND J. D. CONGDON. 1996. Oral deformaties in tadpoles (Rana catesbeiana) associated with coal ash deposition: effects on grazing ability and growth. Freshwater Biology 36:723-730.

Sandhu, S. S., G. L. Mills, and K. S. Sajwan. 1993. Leachability of $\mathrm{Ni}, \mathrm{Cd}, \mathrm{Cr}$, and As from coal ash impoundments of different ages on the Savannah 
River Site. Pages 165-182 in R. F. Keefer and K. S. Sajwan, editors. Trace Elements in coal combustion residues. Lewis, Boca Raton, Florida, USA.

SANCHEZ, J., AND J. BurGER. 1998. Hunting and exposure: estimating risk and future use at nuclear production sites. Risk: Health, Safety and Environment 25:109-118.

SAS INSTITUTE. 1988. SAS/STAT user's guide. Version 6.03. SAS Institute, Cary, North Carolina, USA.

Seaman, J. C., P. M. Bertsch, S. F. Korom, and W. P. Miller. 1996. Physiochemical controls on non-conservative anion migration in coarse-textured alluvial sediments. Ground Water 34:778783.

SharitZ, R. R., AND J. W. GibBons. 1982. The ecology of southeastern shrub bogs (Pocosins) and Carolina bays: a community profile. U.S. Fish and Wildlife Service Publication FWS/OBS-82/04.

South Carolina Department of Natural ReSOURCES. 1996a. 1995-96 commercial fur harvest summary. Furbearer Resources Bulletin Fall 1996:1,7.

1996b. The impact of sport raccoon hunting on deer movement and deer hunting success. Furbearer Resources Bulletin Fall 1996:6.

Stribling, H. L., I. L. Brisbin, JR., AND J. R. SwEeNEY. 1986. Radiocesium concentrations in two populations of feral hogs. Health Physics 50:852854.

Strom, R. N., AND D. S. KABACK. 1992. SRP Base- line hydrogeologic investigation: aquifer characterization groundwater geochemistry of the Savannah River Site and vicinity. Westinghouse Savannah River Company Publication, WSRC-RP92-450, Aiken, South Carolina, USA.

WALKER, S., AND M. SUNQUIST. 1997. Movement and spatial organization of raccoons in north-central Florida. Florida Field Naturalist 25:11-21.

Whicker, F. W., J. E. Pinder, J. W. Bowling, J. J. Alberts, AND I. L. BRIsBIN, JR. 1990. Distribution of long-lived radionuclides in an abandoned reactor cooling reservoir. Ecological Monographs 60:471-496.

, T. G. Hinton, J. Niquette, and J. Seel. 1993. Health risks to hypothetical residents of a radioactively contaminated lake bed. Meeting the challenge: proceedings of the U.S. Department of Energy-ER93 Environmental Remediation Conference 1:619-624.

Wood, J. E., AND E. P. Odum. 1964. A nine-year history of furbearer population on the AEC Savannah River Plant area. Journal of Mammalogy 15:540-551.

Workman, S. W., AND K. W. MCLEOD. 1990. Vegetation of the Savannah River Site: major community types. Savannah River Ecology Laboratory Publication SRO-NERP-19, Aiken, South Carolina, USA.

Received 15 February 1999.

Accepted 11 May 1999.

Associate Editor: Rattner. 